\title{
Innovative ideas of the intelligentsia in the field of management and zoning of the Urals territory
}

\author{
Gulsina Selyaninova* \\ PNRPU, 29, Komsomolsky prospekt, Perm, 614990, Russia
}

\begin{abstract}
The article is devoted to the characteristics of changes in the management and administrativeterritorial structure of the Urals under the regime of A.V. Kolchak (November 1918 - July 1919). These changes took place with the active participation and on the basis of the ideas of the intelligentsia involved in power in this period of Russian history. The administration and zoning of the Urals territories under A.V. Kolchak's regime bore a succession character in relation to the previous regime of a "democratic counter-revolution" that existed during the reign of the Provisional Regional Government of the Urals (August - November 1918). However, the size of the subordinate territories under the Supreme Ruler was more ambitious, which also determined the need to solve more significant administrative tasks and changes in the area of zoning. The regions became large territorial units. They were divided into provinces, counties and volosts. S.S. Postnikov was the head of the Ural region, and the Perm province was ruled by Chistoserdov N.P. Administrators were appointed to rule the counties, who managed to hold a congress of the counties governors of the Perm province in February 1918.
\end{abstract}

\section{Introduction}

The coup in November 18, 1918, which ended the activities of the Directory, put an end to the lingering illusions of the Russian intelligentsia about the possibility of democratic development. The coup by A.V. Kolchak led to the establishment of a new political system in the territories of Siberia and the Urals, which were not subject to Soviet power. Being a supreme ruler, A.V. Kolchak possessed the highest military and civilian power.

Almost within several months after A.V. Kolchak had come to power, there was a restructuring of the management system and the administrative-territorial structure in the subordinate territories [1]. Representatives of the intelligentsia who entered the structures of state power in the Urals and Siberia took an active part in it.

\section{Materials and methods}

This study is based on an analysis of archival documents from the State Archive of the Perm region and the State Archive of the Sverdlovsk Region. Textual analysis of archival sources is complemented by methods of intellectual history and structural-functional analysis.

\section{Results}

Large territorial units were called "krais". The post of the Chief of the Territory was established, who was subordinate to the Minister of Internal Affairs. In the Urals, the Samara-Ufa and Ural Krais were created, but the previous administrative-territorial division into provinces, counties, volosts was also preserved. The territories of the Perm province made up the Ural Krai, but Perm was captured by the Kolchakites only on December 24, 1918. Soon after that, by the end of January 1919, the military and civil administration of the region was formed.

In February 1919, the Zemstvo department of the Ministry of Internal Affairs began to collect information on the territorial division of volosts and counties. This was due to the fact that "the population of some districts arbitrarily, without permission, distributed the boundaries of the former administrative divisions" due to the "inconsistency of existing borders with new conditions, with the emergence of new economic and cultural centers, to which the population naturally gravitates" [9, p. 5].

Based on the petition of the Chief Head of the Ural Krai, the Cherdyn district zemstvo and the TroitskoPechora, Savinoborsk, Ust-Shchugorsk volosts of the Ust-Sysolsk district of the Vologda province, the head of the Ministry of Internal Affairs decided to annex the above listed volosts to the Cherdyn county (district) of the Perm province, since the moment of liberation from the Bolshevik the province were outside the

\footnotetext{
$\bar{*}$ Corresponding author: gsina@mail.ru
} 
administrative connection with the center of the UstSysolsk district, occupied by the Bolsheviks [5, p. 8].

During the offensive of the Red Army in summer 1919 and the abandonment of Perm in the department of general affairs of the Ministry of Internal Affairs, the question of reorganizing the Perm province and dividing it into two units - Perm and Yekaterinburg - was discussed [6, p. 1].

During the functioning of the "white" regime by A.V. Kolchak, the management of the Urals territories was carried out by the Chief of the Ural Territory, who was stationed in Yekaterinburg. This position was introduced by order of the Supreme Ruler on December 10, 1918 [8, p. 18].

The Council of Ministers adopted a special resolution on the issue of the reorganization of administrative bodies in the Urals - "On the abolition of the chief commissioner post for the Urals region of and the administrative bodies established by the regional government of the Urals". The Chief of the Ural Krai was instructed to determine the gradualness and order of this reorganization. The resolution, signed by the Chairman of the Council of Ministers P. Vologodskiy on December 20, 1918, was approved by Admiral A.V. Kolchak on December 28 [3, p.33].

The forty-eight-year-old nobleman, mining engineer with the rank of collegiate councilor Sergei Semenovich Postnikov, who had previously worked in the Urals in the Theological Mining Society from 1914 to 1918 , became the Chief of the Ural Krai. On August 9, 1918, he was appointed Minister of Trade and Industry of the Siberian Government and at the same time was a commissioner of the Siberian government under the Council of VOPU [15, p. 120]. After being appointed as a Chief of the Ural Krai, S.S. Postnikov also retained the position of assistant minister of trade and industry of the Russian government [15, p.131].

S.S. Postnikov was appointed to the post by the decree of the Supreme Ruler. Colonel Domontovich, the commander of the 1 st Ulan regiment, became his assistant and deputy [8, p. 20].

Order No. 7 of the Chief of the Ural Krai of January 3, 1919 stated that he should be contacted on issues beyond the competence of subordinate bodies of local and provincial administration, and "not subject, remembering that they are responsible for supporting the state and destroying its enemies, and that every minute of delay through diverting them from their direct work can be disastrous for Russia" [8, p. 18].

The Chief of the Ural Krai was the successor of the departmental chief directorates of the Provisional Regional Government of the Urals, which, having been created in August 1918, functioned until December 1918. The chief executives (ministers) of the Provisional Regional Government of the Urals were replaced by commissars and other officials.

The first orders of S.S. Postnikov touched upon the issues of reorganization of power structures in the Urals. The right to determine the procedure for this reorganization was granted to him by a decree of the
Council of Ministers of December 20, 1918 [7, p. 33]. In a telegram dated January 22, 1919, S.S. Postnikov expressed the demand for general issues to be resolved, having previously agreed on them, and also notified that the approval of certain persons in different positions is made by the Minister of Internal Affairs through the Chief of the Ural Krai [7, p. 22].

On December 31, 1918, the main department of agriculture and state property of the VOPU was disbanded. The Perm Department of Agriculture and State Property became its successor [8, p. 19]. Instead of the chief executive, a labor commissar for the Ural region (krai) was appointed (both terms are found in the documents). It was N.M. Obukhov [8, p. 17].

On January 1, 1919, the main department of public education was disbanded [8, p. 17]. V.M. Anastasyev, who retained the position of director of the Yekaterinburg School of Art and Industry, was appointed a trustee of the Orenburg educational district [11, p. 27].

The question connected with the seat of the Committee (Congress) of the Constituent Assembly members was decided by S.S. Postnikov in favor of Yekaterinburg [8, p. 14]. Former Deputy Chief Executive Officer of Public Education VOPU A.M. Rozov, the teacher of the Yekaterinburg real school, and the assistant professor of the Ural Mining Institute, the teacher of the Yekaterinburg Teachers' Institute M.N. Khitrin were appointed to the posts of district inspectors [8, p. 13].

By order of the All-Russian Government, the Main Directorate of Mining Affairs of the Urals was disbanded, and in its place the Ural Mining Directorate was restored, headed by the Chief Head of the Ural Mining Plants, Mining Engineer Alexander Andreyevich Ivanov. But the Ural Industrial Committee continued to function in its former composition under the chairmanship of the mining engineer A.E. Gutta $[8, \mathrm{p}$. $10]$.

At the disposal of S.S. Postnikov, there were funds for the reorganization that were issued against receipt to newly appointed persons. So, V.M. Anastasyev, still in the capacity of the chief manager of the VOPU, was given an advance payment "for the maintenance of personnel under the authorized representative of the Ministry of Public Education and for economic expenses in the amount of four thousand rubles" already on January 3, 1919 [11, p. 26]. Funds were also allocated to address issues that can hardly be called priority ones. On January 20, 1919, 7 thousand rubles were allocated for the purchase of collections of antiquities from the museum of the art and industrial school to the trustee of the Orenburg educational district V.M. Anastasyev [11, p. 27].

The head of the Ural Krai was directly subordinate to the governor of the Perm province. The governor of the province during the reorganization of the management system under A.V. Kolchak began to be called the provincial commissar, in his subordination were the governors of the counties (former county 
commissars) [10, p. 2]. Nikolai Pavlovich Chistoserdov was appointed to the post of governor of the province. In August 1918, he was the head of the administrative department of the Yekaterinburg garrison, and after the Kolchak coup - "assistant to the commissioner for the maintenance of state order and public peace" in Yekaterinburg [16, p. 3; 18, p. 5]. Mikhail Vasilyevich Kukaretin, who for a long time was an indispensable member of the Perm provincial presence, became the assistant-deputy governor of the province [2]. By the way, it should be noted that before January 4, 1919, that is, before N.P. Chistoserdov, he served as governor of the province. By the end of January 1919, the office of the governor of the Perm province and the staff of the provincial government were formed. Provincial veterinary inspector A.I. Yutsevich; provincial medical inspector P.P. Shipilin; provincial engineer E.I. Artemov, provincial architect E.E. Pehler were appointed to their positions [15, p. 108]. On March 5, 1919, P.I. Danilov was appointed chief of the city police [15, p. 126].

Managing the Perm province, N.P. Chistoserdov dealt mainly with various socio-economic issues, including, for example, land management issues, the tasks of supplying towns with fuel, building materials, etc. $[14$, p. 263$]$.

Since Perm remained the provincial center, and the Chief Head of the Ural Krai was in Yekaterinburg, there was some inconvenience in management. At the end of January 1919 S.S. Postnikov agreed in Omsk on the transfer of the governor of the province to Yekaterinburg. However, the intervention of the commander of the 1st Central Siberian Corps, Lieutenant General Pepelyaev, canceled the relocation of the provincial presence $[17$, p. 3, 6]. Pepelyaev's order aroused the indignation of S.S. Postnikov, who stated that the chief heads of the region, being the highest representatives of the supreme power at the local level, are exclusively subordinate to the Supreme Ruler. And the transfer of the province administration to Yekaterinburg was agreed with him, as well as with the Chairman of the Council of Ministers and the Minister of Internal Affairs $[17$, p. 5, 5rev.]. But the protest hung out in the air.

All branches of civil administration within the Perm province were subordinated to the chief of the Ural Krai [8, p. 18].

Managers were appointed at the head of the counties. In mid-February 1919, a congress of county managers of the Perm province was held. S.S. Postnikov recommended that the issue of volost zemstvos should be comprehensively considered at it [12, p. 23]. Before the congress, the county managers in their telegrams outlined a range of problems that needed to be discussed. Among them were the development of regulations on county governors, the staff and credits of the chancellery, relations with other public institutions and control over them, the differentiation of the functions of military and civil authorities in the frontline zone, etc. [12, p. 19, 26].
The congress was chaired by the governor of the province, N. P. Chistoserdov. In addition to him, his deputy M. V. Kukaretin, permanent members of the provincial presence N. E. Andriolli, N. P. Chernyaev took part in the work of the congress; the governors of the counties arrived from their places: Perm - A. N. Ilyin, Kungur - A. I. Yushkov, Solikamsk - A. S. Komarov, Krasnoufim - A. N. Nefedov, Shadrin - E. N. Sumarokov, Irbit - M. A. Atmakin, Verkhotursky - E. K. Bekman, Cherdynsky - M. Ya.Kazantsev, Yekaterinburg - V. A. Startsev and Kamyshlovsky - A. N. Chechetkin [13, p. 1].

At the congress, the Regulations on the Chief head of the Ural Krai were announced, according to which "the latter is granted the right to make orders before the publication of the grounds for such in the legislative order" $[13$, p. 8]. All decisions of the city and zemstvo district self-governments must be submitted to the Governor of the province for consideration. The participants of the congress were also familiarized with the still valid Regulations of the All-Russian Provisional Government (Directory) on county commissars who received the status of county managers under A.V. Kolchak. They were assigned the rights and duties of the leaders of the nobility, the chairmen of the administrative committees responsible for the safety of citizens, the chairmen of the evaluation commissions, as well as the chairmen of the zemstvo administrative presence in charge of land use questions [13, p. 1rev.].

A heated discussion was caused by the question of dividing the districts of the Perm province into categories in accordance with the salaries of the content received. The Congress found it most fair to divide the counties (uyezds) into the following categories: the 1st category - Perm and Yekaterinburg with the counties, the 2nd category - Kungur, Krasnoufimsk, Solikamsk, Cherdyn, Verkhoturye, Irbit, Kamyshlov and Shadrinsk with the counties [13, p. 3]. Later, in March 1919, taking into account this decision, the Council of Ministers adopted the "Schedule of dividing the localities of the provinces of Orenburg, Perm and Ufa and the Turgay region into categories for the production of maintenance for employees of government agencies" [4, p. 9].

The consideration of the issue of the relationship of county managers with the police and military authorities was relevant for the current moment. It was decided that the military commandants are only agents of the commissioner for protection, and the investigative commissions should belong to the civilian department, but a special law is needed about them, the release of which is expected soon [13, p. 3]. The congress discussed the question of the states of the county governors' offices; in the organization of county congresses, it was stated that it was necessary to adhere to the decisions of the Provisional Government of 1917, since there were no orders to abolish them [13, p. 4rev.].

Some of the county managers spoke in favor of restoring the normal activities of the volost administrations and granting them a broader right to monitor the activities and record-keeping of the volost zemstvos. This question was raised due to the fact that 
the zemstvos were turning from self-government bodies into part of the administrative apparatus with police functions, and, therefore, it was necessary to extend the supervision of county managers to the entire range of activities of the volost self-governments. N.P. Chistoserdov explained that the county managers already had the right to audit all the bodies of the zemstvo's selfgovernment, since it belonged to the provincial commissar, and "the latter can entrust the right to audit the county commissar" [13, p. 5, 7, 8rev.].

The county managers sought to be able to impose administrative penalties on the rural administration bodies - the village elders. This requirement was met $[13$, p. 6].

The congress approved the staffing of the office of county managers, which included a secretary, two assistants, a registrar, two scribes, one typist, a messenger, a watchman, an accountant, a veterinarian and a veterinary paramedic, and medical personnel [13, p. 11, 11rev.]. The expenses for the maintenance of the states had to be "requested through the governor of the province by submitting special estimates" [13, p. 13].

\section{Discussion}

Although Russian historians have turned to the study of public administration and zoning in the Urals and Siberia during the Civil War, here we can note mainly works related to the analysis of changes in the state structures of Siberia, such as the study of A.N. Nikitin [1]. The question of the ideas and activities of the intellectuals under the Kolchak regime in transforming the system of administration and zoning in the Urals remained outside the scope of existing studies.

\section{Conclusion}

Thus, when forming the bodies of state power and local self-government under the regime of A.V. Kolchak, in the sphere of zoning, the authorities relied primarily on the innovative ideas of the intelligentsia, who actively formed the system of management and administrativeterritorial structure of the Urals and sought to create stable conditions for peaceful life in its territories.

The management and zoning of the territories of the Urals under A.V. Kolchak was of a continuous nature in relation to the previous regime of "democratic counter revolution" that existed during the rule of the Provisional Regional Government of the Urals (August-November 1918). However, the size of the subordinate territories under the Supreme Ruler was more extensive, which determined the need to solve more significant administrative tasks and changes in the field of zoning. The regions became large territorial units. They were divided into provinces, counties, and volosts, and county managers were appointed at the head of the counties.

\section{References}

1. A N Nikitin ם.D. Statehood of "white" Russia: formation, evolution, and collapse. (Moscow: National Institute of Business, 2004)

2. Liberation of Russia (Perm). 1919. 1 Jan

3. State Archive of the Perm region, form R-746, inv. 1, doc. 1

4. State Archive of the Perm region, form R-746, inv.1, doc. 3

5. State Archive of the Perm region, form R-746, inv. 1, doc. 8

6. State Archive of the Perm region, form R-746, inv. 1, doc. 10

7. State Archive of the Perm region, form R-746, inv.2, doc. 1

8. State Archive of the Perm region, form R-746, inv. 2, doc. 2

9. State Archive of the Perm region, form R-746, inv. 2, doc. 3

10. State Archive of the Perm region, form R-746, inv.2, doc. 4

11. State Archive of the Perm region, form R-746, inv.2, doc. 11

12. State Archive of the Perm region, form R-746, inv.2, doc. 13

13. State Archive of the Perm region, form R-746, inv.2, doc. 14

14. State Archive of the Perm region, form R-746, inv.2, doc. 28

15. State Archive of the Sverdlovsk region, form P-1956, inv.1, doc. 1

16. State Archive of the Sverdlovsk region, form P-1956, inv.1, doc. 2

17. State Archive of the Sverdlovsk region, form P-1956, inv.1, doc. 44

18. State Archive of the Sverdlovsk region, form P-1957, inv. 1. doc. 15 